\title{
Pendrin, a Novel Transcriptional Target of the Uroguanylin System
}

\author{
Julia Rozenfelda,b Osnat Tala Orly Kladnitskya,b Lior Adler ${ }^{\mathrm{a}}$ Edna Efratia,b \\ Stephen L. Carrithers ${ }^{c}$ Seth L. Alperd,e Israel Zelikovic ${ }^{a, b}$
}

aLaboratory of Developmental Nephrology, Department of Physiology and Biophysics, Faculty of Medicine, Technion-Israel Institute of Technology, and 'Division of Pediatric Nephrology, Rambam Medical Center, Haifa, Israel; 'Sequela, Inc. Pewee Valley, KY, 'Renal Division, Division of Molecular and Vascular Medicine, Center for Vascular Biology Research, Beth Israel Deaconess Medical Center and eHarvard Medical School, Boston, MA, USA

\section{Key Words}

Renal tubule - Chloride transport - Anion exchange - Promoter - Guanylin peptides • Guanylyl cyclase $\mathrm{C} \cdot$ Heat shock factor $\cdot$ Electrolyte homeostasis

\begin{abstract}
Guanylin (GN) and uroguanylin (UGN) are low-molecular-weight peptide hormones produced mainly in the intestinal mucosa in response to oral salt load. GN and UGN (guanylin peptides) induce secretion of electrolytes and water in both intestine and kidney. Thought to act as "intestinal natriuretic factors", GN and UGN modulate renal salt secretion by both endocrine mechanisms (linking the digestive system and kidney) and paracrine/autocrine (intrarenal) mechanisms. The cellular function of GN and UGN in intestine and proximal tubule is mediated by guanylyl cyclase C (GC-C)-, cGMP-, and G protein-dependent pathways, whereas, in principal cells of the cortical collecting duct (CCD), these peptide hormones act via GC-Cindependent signaling through phospholipase $\mathrm{A}_{2}\left(\mathrm{PLA}_{2}\right)$. The $\mathrm{Cl}^{-} / \mathrm{HCO}_{3}^{-}$exchanger pendrin (SLC26A4), encoded by the PDS gene, is expressed in non- $\alpha$ intercalated cells of the CCD. Pendrin is essential for CCD bicarbonate secretion and is also involved in $\mathrm{NaCl}$ balance and blood pressure regulation. Our recent studies have provided evidence that pendrin-mediated anion exchange in the CCD is regulated at the transcriptional level by UGN. UGN exerts an inhibitory effect on the pendrin gene promoter likely via heat shock factor 1 (HSF1) action at a defined heat shock element (HSE) site. Recent studies have unraveled novel roles for guanylin peptides in several organ systems including involvement in appetite regulation, olfactory function, cell proliferation and differentiation, inflammation, and reproductive function. Both the guanylin system and pendrin have also been implicated in airway function. Future molecular research into the receptors and signal transduction pathways involved in the action of guanylin peptides and the pendrin anion exchanger in the kidney and other organs, and into the links between them, may facilitate discovery of new therapies for hypertension, heart failure, hepatic failure and other fluid retention syndromes, as well as for diverse diseases such as obesity, asthma, and cancer.
\end{abstract}

Copyright $\odot 2013$ S. Karger AG, Basel 


\section{Introduction}

Guanylin (GN) and uroguanylin (UGN) peptides are produced mainly in the intestinal mucosa in response to oral salt load and induce salt and water excretion in both the intestine and the kidney. The pendrin/SLC26A $4 \mathrm{Cl}^{-} / \mathrm{HCO}_{3}^{-}$exchanger, encoded by the PDS gene, is expressed in cortical collecting duct (CCD) non- $\alpha$ intercalated cells and plays a role in acidbase balance, $\mathrm{NaCl}$ balance and blood pressure control. Intensive research over the past two decades on the molecular mechanisms underlying the operation of the GN/UGN system and the pendrin exchanger has shed light on the mode of action of these two important systems and has provided new insight into their biological roles.

In this review, we will discuss the molecular mechanisms and signal transduction pathways involved in the action of the GN/UGN system and the pendrin exchanger in the kidney and other organ systems. We will review new findings on the molecular link between these two systems leading to regulation of distal nephron salt excretion. We will then summarize new data on non-classical roles of the GN/UGN system in various organs and in diverse cellular processes. Finally, the potential use of the guanylin peptides as therapeutic agents in a variety of disease states will be discussed.

\section{The Guanylin Peptides}

The Guanylin Peptides: Structure and Function

GN and UGN are low-molecular weight peptide hormones produced mainly in the intestinal mucosa and released both luminally and into the circulation in response to oral salt load. GN and UGN induce secretion of electrolytes and water in both intestine and kidney by cGMP-dependent and independent mechanisms [1-5] (see below).

GN and UGN consist of 15 and 16 amino acids, respectively (Fig. 1), and both possess two disulfide bonds between positions 7 and 15 [6]. GN and UGN are similar in structure and activity to the secretory diarrhea-causing E. coli heat-stable enterotoxin (STa) [7-9]. The human genes encoding GN and UGN, respectively termed GCAPI/GUCA2A (Guanylyl Cyclase Activating Peptide I) and GCAPII/GUCA2B (Guanylyl Cyclase Activating Peptide II), and each consists of 3 exons, are located on chromosome 1 [10-11] (Fig. 1).

GN and UGN are synthesized as preprohormones primarily in the intestine $[2,12]$ as well as in the kidney, adrenals, heart, adenohypophysis, airways, and the reproductive system [13-16]. Proteolytic processing of the preprohormone to the inactive propeptide form has been shown in both intestine and kidney [17-19]. Plasma GN circulates only as proGN $[20,21$ ), whereas plasma UGN is present as both propeptide (proUGN) and active forms $[18,21,22]$. The inactive proUGN undergoes proteolytic conversion to bioactive UGN by renal tubular brush border membrane-associated enzymes [9, 19, 23], producing high concentrations of UGN in the urine. In contrast to the endopeptidase-resistant UGN and STa peptides, GN peptide is rapidly degraded and inactivated by renal tubular endopeptidases $[17,24]$, which accounts for the absence of bioactive GN in the urine.

The effect of the guanylin peptides on renal electrolyte and water handling is achieved via both endocrine and paracrine/autocrine mechanisms $[3,5,18,19,25,26]$ (see below). In this important role, the guanylin peptides join other well- known regulatory systems of body fluid and electrolyte balance, including the renin-angiotensin-aldosterone system, argininevasopressin, atrial natriuretic peptide (ANP) and its homologs, and the nitric oxide (NO) system $[3,5,27]$. However, the regulatory role of UGN in sodium balance that is triggered by alterations in dietary salt intake differs from the other sodium regulatory systems that are triggered by changes in extracellular volume and arterial pressure $[5,19]$.

Guanylin Peptides in the Intestine

a. Localization and actions. GN and UGN are co-expressed along the intestinal tract with guanylyl cyclase C (GC-C), the principal guanylin receptor $[28,29]$. UGN is produced and 


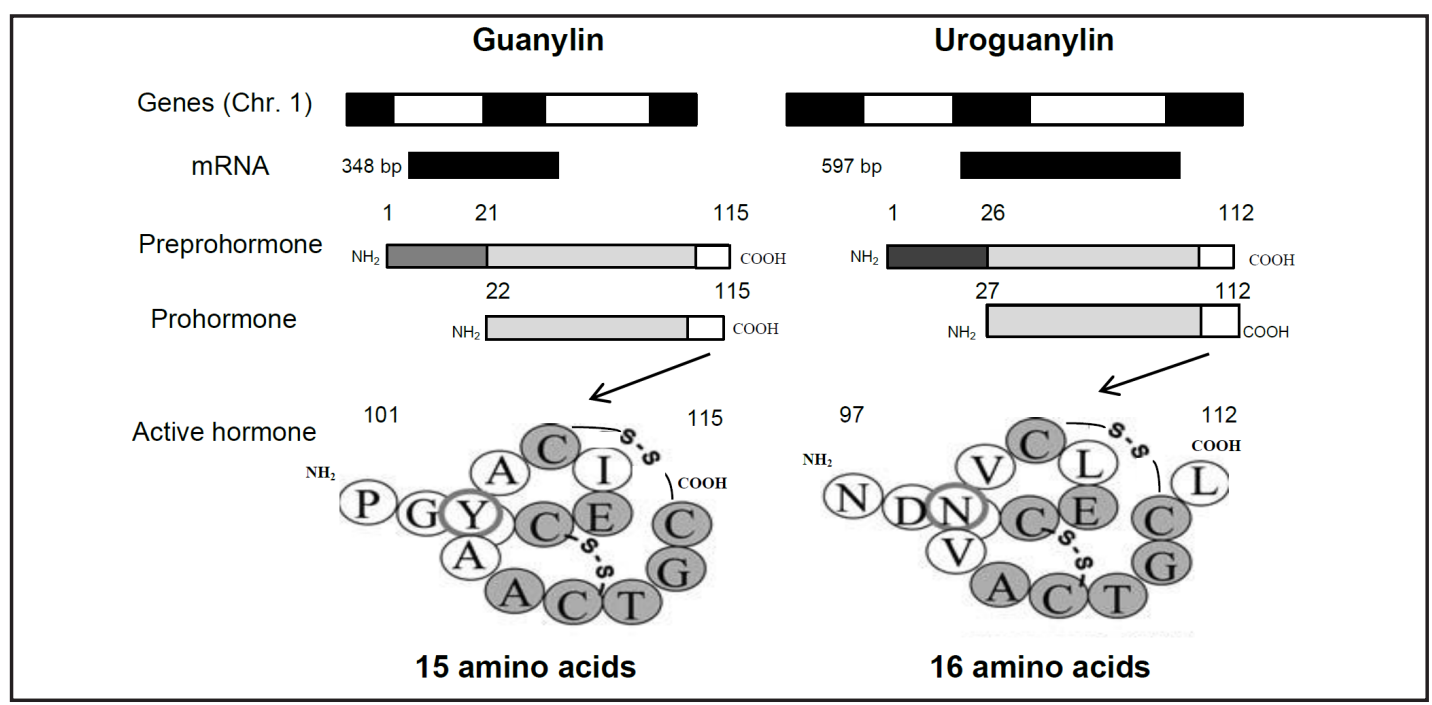

Fig. 1. Amino acid sequence of human guanylin and human uroguanylin. Genes encoding guanylin and uroguanylin are located on chromosome 1 and each consists of 3 exons (black rectangles) and 2 introns (white rectangles). The numbers above the schemes of the preprohormones, prohormones, and active hormones represent amino acid numbers. Gray circles in the structures of the active hormones (bottom of figure) indicate identical amino acids in both peptides (Modified from Ref. 26 with permission).

expressed in enterochromaffin cells predominantly in the jejunum, whereas GN is produced in goblet cells predominantly in the ileum to the proximal colon [30-34]. In response to oral salt load, GN and UGN are secreted into the intestinal lumen and into the circulation and activate the enterocyte luminal membrane receptor GC-C. The increased intracellular cyclic guanosine monophosphate (cGMP) directly inhibits luminal NHE3 $\mathrm{Na}^{+} / \mathrm{H}^{+}$exchanger activity and indirectly (by activating protein kinase A (PKA) and protein kinase G II (PKG II)) stimulates luminal cystic fibrosis transmembrane regulator (CFTR) and $\mathrm{Cl}^{-} / \mathrm{HCO}_{3}^{-}$exchange activities, thus reducing $\mathrm{Na}^{+}$absorption and increasing secretion of $\mathrm{Cl}^{-}, \mathrm{HCO}_{3}^{-}, \mathrm{K}^{+}$and $\mathrm{H}_{2} \mathrm{O}$ [3]. UGN activity peaks at $\mathrm{pH} 5.0$ whereas GN activity is highest at $\mathrm{pH} 8.0$ [3].

$b$. Human Mendelian diseases of GUCY2C mutations. A gain-of-function missense mutation in GUCY2C, encoding guanylyl cyclase 2C, was discovered in a large family with autosomal dominant familial diarrhea of early onset, associated with increased susceptibility to inflammatory bowel disease, small bowel obstruction, and esophagitis [35]. The mutant guanylyl cyclase over-expressed in HEK-293 cells conferred greatly elevated levels of cGMP, speculated to promote increased activity of CFTR in patient enterocytes. In contrast, lossof-function mutations in GUCY2C found in two unrelated consanguineous families caused autosomal recessive meconium ileus (intestinal obstruction in the newborn) in the absence of pathogenic CFTR mutations [36].

\section{Guanylin Peptides in the Kidney}

a. Guanylin peptides in the enterorenal axis. Traditionally, GN and UGN have been thought to play a major role in the regulatory link between the intestine and the kidney by increasing urinary $\mathrm{NaCl}$ and water excretion in response to dietary $\mathrm{NaCl}$ intake (but not intravenous administration), thereby serving as "intestinal natriuretic factors" $[3,37,38]$. Studies in rats [39], rabbits [40,41] and humans [42-44] showed that an equivalent sodium load is more rapidly excreted after oral than after intravenous administration. Oral salt loading of UGN knockout mice resulted in impaired natriuresis and increased blood pressure as compared with wild-type mice $[27,45]$. In contrast, intravenous administration of salt in UGN-deficient mice elicited natriuresis equivalent to that of wild-type animals [45]. Salt-loaded humans [22] show higher concentrations of UGN in the blood and urine. GN/UGN exert their effect on the kidney without changing the glomerular filtration rate or renal blood flow $[1,25,46]$. 
Noteworthy studies by Goy and coworkers $[18,19]$ demonstrated that proUGN is the endocrine agent released from the intestine into the circulation in response to oral salt intake, and that it is converted in the kidney to active UGN. The N-terminal prosequence has been proposed to serve as a specialized delivery vehicle shielding UGN from destruction or premature function during its passage from the intestine to the kidney [18]. The same authors have provided evidence for two human UGN isomers with saluretic activity, A and B [47]. The A isomer activates the GC-C receptor, while the B isomer is a very weak agonist of this receptor but has potent natriuretic activity in the kidney.

Together, these findings have demonstrated an essential role for GN/UGN in the enterorenal axis that serves to maintain salt homeostasis.

b. The intrarenal guanylin peptide system. Accumulating data have provided evidence that guanylin peptides are produced in the kidney (likely in response to hypernatremia) and have paracrine/autocrine functions in the cells along the nephron [5, 48, 49]. GN and UGN mRNAs are expressed in rodent and human kidney epithelial cells $[3,12,15,32,50$ 52]. Mice or rats fed high salt diets show increased UGN mRNA in both intestine and kidney $[52,53]$. These salt-loaded animals maintain normal plasma concentrations of UGN [51] and proUGN [54], while excreting significantly more UGN in the urine than control animals. Moreover, high extracellular [ $\mathrm{NaCl}]$ influences UGN expression in cultured kidney cells [52, $53,55,56]$. Qian et al. [49] in a recent, thorough experimental study in rats, demonstrated high proUGN abundance locally synthesized in renal distal tubule segments. The authors provided evidence for an intrarenal UGN system that differs from the intestinal system in its regulatory mechanisms and in the receptor targeted by the peptide, which is not the enteric UGN receptor, GC-C.

The traditional view that the guanylin peptides produced in the intestine act as hormones in the kidney has been challenged by a recent clinical study in humans $[48,57]$. The authors found no difference in sodium excretion following equivalent oral or intravenous sodium loads in subjects maintained on diets either high or low in sodium, and serum concentrations of proGN and proUGN did not increase during the course of the study.

With the exception of this human study, the existing rodent data support the notion that both endocrine-mediated and local, paracrine/autocrine actions of UGN in the kidney operate in tandem as biological mechanisms for regulation of sodium balance in the postprandial state $[5,48]$.

The mode of action and signaling pathways for GN/UGN differ between various nephron segments [3, 25, 58-61] as described below.

c. GN/UGN in the proximal tubule. GN/UGN action in the proximal tubule is mediated via two alternative $\mathrm{pH}$-sensitive signaling pathways, a GC-C-mediated, cGMP-dependent pathway active at acidic $\mathrm{pH}$, and a pertussis toxin (PTX)-sensitive, G protein-dependent pathway active at alkaline $\mathrm{pH}[3,60]$. Unlike the diffuse distribution of intestinal GC-C expression, renal GC-C expression in mouse is limited to the proximal tubule [52]. In both tissues, GC-C activation by UGN peaks at pH 5.0 and is markedly lower at pH 8.0 [60]. Proximal tubular GC-C activation by UGN at low pH produces natriuresis and diuresis through inhibition of both basolateral $\mathrm{Na}^{+}-\mathrm{K}^{+}$-ATPase and luminal $\mathrm{Na}^{+} / \mathrm{H}^{+}$exchange and $\mathrm{K}^{+}$channels, whereas at high $\mathrm{pH}$, UGN produces kaliuresis, at least in part, through cGMP-independent, G-proteindependent $\mathrm{K}^{+}$channel stimulation $[3,60]$.

d. GN/UGN in principal cells of the cortical collecting duct. The renal CCD plays an important role in acid-base balance and electrolyte homeostasis and includes principal cells and intercalated cells $(\alpha, \beta$ and non- $\alpha$, non- $\beta$ ) [62]. The CCD principal cell has been considered a target for GN/UGN action $[3,27,58,61]$. The persistent natriuresis of GC-C knockout mice treated with UGN [25], and the lack of GC-C mRNA in the CCD $[49,52,58]$ suggest GC-C and cGMP-independent signaling by UGN in this nephron segment. This signaling involves G-protein-dependent phospholipase $\mathrm{A}_{2}\left(\mathrm{PLA}_{2}\right)$ activation, generating arachidonic acid to inhibit luminal $\mathrm{K}^{+}$channels (ROMK) [61]. The resultant decreased $\mathrm{K}^{+}$secretion and reduced driving force for $\mathrm{Na}^{+}$reabsorption leads, in turn, to natriuresis and diuresis $[25,58,61]$. 


\section{The Anion Exchanger Pendrin}

\section{The Anion Exchanger Pendrin in the Kidney}

The anion exchanger pendrin (SLC26A4), which is encoded by the PDS gene, is located at the luminal membrane of $\beta$ and non- $\alpha$, non- $\beta$ intercalated cells of the CCD [62]. Pendrin contributes to acid-base balance by secreting $\mathrm{HCO}_{3}$ - into the tubular lumen in exchange for luminal $\mathrm{Cl}^{-}$[63], and that same $\mathrm{Cl}^{-}$reabsorption regulates body fluid homeostasis and blood pressure [64-66]. Pendrin protein expression in the apical membrane of $\beta$ intercalated cells is increased by systemic $\mathrm{HCO}_{3}^{-}$loading and decreased by acid loading [67-69]. Systemic and tubule lumen $\mathrm{Cl}^{-}$concentrations and/or Cl- loads regulate pendrin protein levels and activity $[65,66,70]$.

The importance of intercalated cells, in general, and pendrin, particularly, in $\mathrm{NaCl}$ balance and blood pressure control has been clearly shown by recent studies. These include studies demonstrating 1 ) the role of pendrin in the pathogenesis of mineralocorticoid and/ or angiotensin II - induced hypertension [64, 71, 72]; 2) the functional link between pendrin and $\mathrm{Na}^{+}$transport mechanisms in the CCD, including the amiloride-sensitive epithelial $\mathrm{Na}^{+}$ channel of the principal cell, ENaC $[73,74]$ and the $\mathrm{Na}^{+}$-driven $\mathrm{Cl}^{-} / \mathrm{HCO}_{3}^{-}$exchanger of the $\beta$ intercalated cell, NDCBE/SLC4A8 [75]; 3) the $\mathrm{Cl}^{-}$-sensitive hypertension observed in mice overexpressing pendrin in intercalated cells [76]; and 4) the severe salt wasting and volume depletion observed in pendrin/ $\mathrm{NaCl}$ cotransporter double knockout mice [77].

Our deletion analysis of the 5'-flanking region of the human PDS (hPDS) gene defined both positive and negative regulatory elements in the $h P D S$ promoter and proposed a major role for these control elements in the renal epithelial cell-specific, regulated expression of this gene [78]. We have also shown that pendrin is transcriptionally regulated by systemic $\mathrm{pH}$ and aldosterone $[78,79]$ as well as by extracellular $\mathrm{Cl}^{-}$concentration [80] in renal epithelial cells, further demonstrating the important role of pendrin in electrolyte balance and blood pressure regulation.

\section{Transcriptional Regulation of the Pendrin Gene by UGN}

Despite accumulating data on renal expression and function of guanylin peptides, the cellular and molecular pathways mediating UGN action in the CCD remain poorly understood. Considering the major role of both guanylin peptides and pendrin in the regulation of total body $\mathrm{NaCl}$ content, maintenance of extracellular fluid volume and control of blood pressure, we investigated UGN modulation of pendrin expression and explored the molecular mechanisms responsible for this modulation [81].

We first showed that injection of UGN into mice resulted in decreased renal expression of pendrin mRNA and protein. UGN also decreased endogenous pendrin mRNA levels in HEK293 cells [81]. We next examined possible modulation by UGN of human PDS (hPDS) transcription at the level of the $h P D S$ promoter [81].

a. Effect of UGN on hPDS promoter activity. The $4.2 \mathrm{~kb}$ hPDS promoter and consecutive 5 '-deletion products were cloned into luciferase reporter vectors and transiently transfected into HEK293 cells. Exposure of transfected cells to UGN decreased hPDS promoter activity and suggested the presence of a UGN response element (URE) between nt -1433 and -1044, upstream of the hPDS translation start site [81].

To further define the putative URE located within this $389 \mathrm{bp}$ promoter region, fine scale deletion analysis was performed. The results suggested that the URE required for transcriptional regulation by UGN was contained within the 52 bp between $n t-1153$ and -1101 within the $h P D S$ promoter [81].

b. Heat shock element (HSE)-dependence of hPDS promoter regulation by UGN. This 52 bp segment included was shown by bioinformatic analysis to include a consensus heat shock element (HSE) at nt -1119 to -1115 (see below). We therefore examined whether the effect of UGN on the promoter was HSE-dependent. For this purpose, a nucleotide within the HSE motif was point mutated in both a vector containing the 1.4-kb 5'-flanking region of hPDS termed PL1.4 and a vector containing the 110-bp hPDS distal promoter region termed 
A.

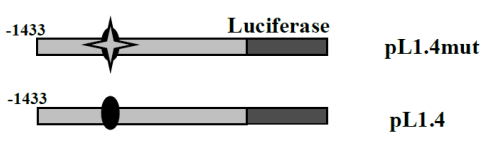

B.

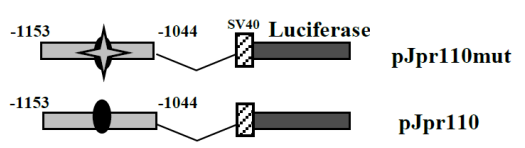

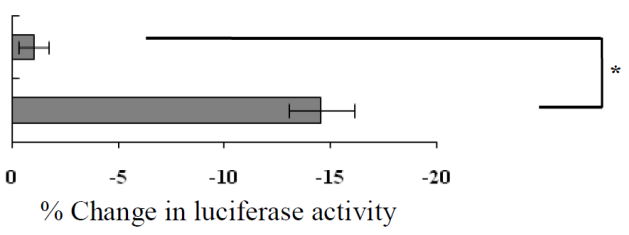

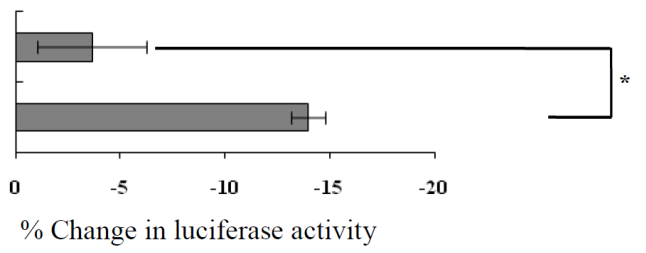

Fig. 2. Role of a defined heat shock element (HSE) in the effect of UGN on the hPDS promoter in HEK293 cells. A: effect of UGN on the 1.4-kb 5 '-flanking region. Cells were transfected with $0.3 \mu \mathrm{g}$ pGL3-basic or 0.3 $\mu \mathrm{g}$ pGL3-basic containing the 1.4-kb 5'-flanking region of hPDS (pL1.4) or $0.3 \mu \mathrm{g}$ pL1.4 harboring a pointmutated HSE site (pL1.4mut). Cells were exposed to $1 \mu \mathrm{M}$ UGN or control medium for $24 \mathrm{~h}$, and luciferase activity was then measured. B: effect of UGN on the 110-bp HSE-containing DNA region. Cells were transfected with $0.3 \mu \mathrm{g}$ pGL3-SV40 minimal promoter vector or $0.3 \mu \mathrm{g}$ pGL3-SV40 containing the 110-bp hPDS promoter fragment with a wild-type HSE site (pJpr110) or $0.3 \mu \mathrm{g}$ pJpr110 harboring a point-mutated HSE site (pJpr110mut). Cells were exposed to UGN or control as in A, and luciferase activity was measured. Luciferase activity in A and B was normalized to $\beta$-galactosidase activity. Data represent the $\%$ change in luciferase activity in cells exposed to experimental medium (with $1 \mu \mathrm{M}$ UGN) relative to cells exposed to control medium (without UGN). Whereas UGN inhibited luciferase activity in cells transfected with the wild-type 1.4-kb promoter fragment (A) or the wild-type 110-bp fragment (B), mutating the HSE site in either of these fragments markedly diminished the UGN-induced effect. Values are means \pm standard error (SE) of the mean of 3-5 independent experiments, each performed in quadruplicate. ${ }^{*} \mathrm{P}<0.05$ (adapted from Ref. 81 with permission).

pJpr110 (see Fig. 2A,B). HEK 293 cells transfected with these constructs were exposed to UGN. The decreases in wild-type HSE -containing pL1.4 (Fig. 2A) and pJpr110 (Fig. 2B) activities following UGN treatment were greatly attenuated in cells transfected with the corresponding mutant promoter fragments. These findings suggested that UGN modulates hPDS activity by a mechanism that requires the promoter's HSE site at nt 1119 to -1115 [81].

c. Heat shock factor 1 (HSF1) regulates promoter activity through the HSE. We first showed the expression of mRNA encoding heat shock factor 1 HSF1 (a transcription factor that recognizes the HSE motif; see below) in HEK293 cells. Next we showed that transfection of HSF1 small interfering RNA (siRNA) markedly reduced endogenous HSF1 mRNA levels in HEK 293 cells. A 30\% reduction in hPDS mRNA levels by UGN treatment of HEK293 cells transfected with control siRNA (Fig. 3 middle) was completely abolished in HEK 293 cells transfected with HSF1 siRNA (Fig. 3 right). These findings provided strong evidence for involvement of HSF1 in regulation of the PDS gene by UGN.

The HSFs comprise a group of transcription factors that regulate the heat shock response (HSR) [82-84], a fundamental, evolutionarily conserved defense mechanism that protects cells against proteotoxic stresses such as heat, infection, inflammation, and pharmacological or toxicological agents $[82,83]$. The HSFs exert their regulatory activity by binding to specific promoter elements (HSEs) which were first defined upstream of cytoprotective heat shock genes including heat shock protein (HSP)70, HSP90, HSP27 and other molecular chaperonins 
Fig. 3. Effect of heat shock factor (HSF) 1 small interfering RNA (siRNA) on endogenous PDS mRNA levels in UGN-treated HEK293 cells. HEK293 cells were transfected with HSF1 siRNA or control siRNA before treatment with medium containing or lacking UGN $(1 \mu \mathrm{M})$. Subsequently, total RNA was extracted and real-time PCR analysis of the PDS mRNA was performed. Results represent PDS mRNA in cells transfected with HSF1 siRNA compared with cells treated with control siRNA (left), cells transfected with control siRNA and exposed to UGN-containing medium relative to control siRNA-transfected cells exposed to medium without UGN (middle), or cells

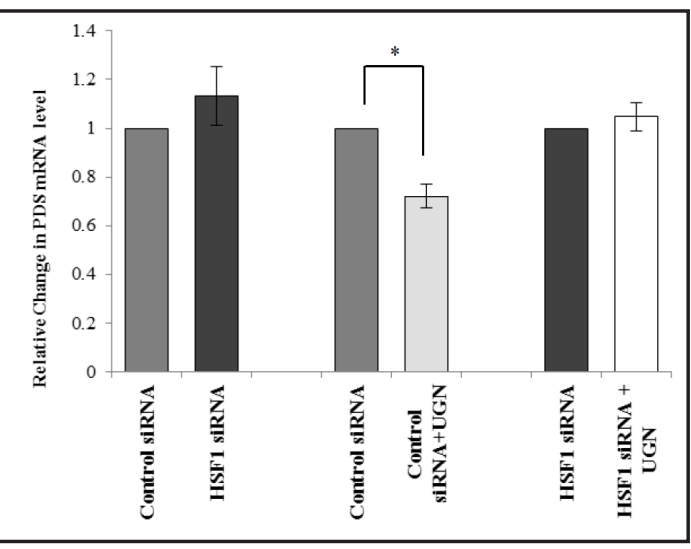
transfected with HSF1 siRNA and exposed to UGN-containing medium relative to HSF1 siRNA-transfected cells exposed to medium without UGN (right). Values were normalized to the housekeeping gene TBP. Values are mean \pm SE of 4 independent experiments, each performed in duplicate. HSF1 siRNA transfection had no effect on PDS mRNA level (left), whereas UGN reduced PDS mRNA level by $30 \%$ in cells transfected with control siRNA (middle), and PDS mRNA level remained unchanged in UGN-treated cells transfected with HSF1 siRNA (right). ${ }^{*} \mathrm{P}<0.05$ (Adapted from Ref. 81 with permission).

of the HSR network [82-84]. While the role of the HSF/HSE system in regulating the activity of HSPs mediating the HSR has been well established, the full range of biological target genes for the HSFs, particularly in the kidney, remains to be established. In addition to the HSP genes, HSEs have been also described in genes encoding proteins with non-chaperonin function, including proteins involved in transport processes [85-87].

Our mutational analysis (Fig. 2 A,B) and RNA-silencing experiments (Fig. 3) provide strong evidence for the involvement of HSF1 and the HSE of the hPDS promoter in transcriptional regulation of the pendrin gene by UGN (Fig. 4). Our study is the first report of a mammalian kidney solute transporter transcriptionally regulated by the HSF/HSE system in a hormone-specific manner.

An evolutionary precedent of this transcriptional regulation is exhibited by the intestinal guanylin system of teleost fish, which plays an important role in seawater adaptation [ 27,88 , 89]. UGN mRNA is upregulated in the intestine and kidney of eels upon seawater exposure $[88,89]$. The primary structure of UGN, conserved throughout vertebrate evolution, suggests that UGN-mediated regulation of systemic $\mathrm{Na}^{+}$balance is the mammalian counterpart of UGN-mediated osmoregulation in teleost fishes of both fresh and salt water environments [27]. Our findings demonstrating the involvement of the stress-stimulated HSF/HSE axis in the UGN-induced modulation of pendrin gene transcription support this notion. These findings also raise the possibility of an adaptive chloriuretic response to osmotic or salt load stress mediated in the kidney by this novel UGN-HSR-pendrin connection.

Taken together, our findings have identified the pendrin $\mathrm{Cl}^{-} / \mathrm{HCO}_{3}^{-}$exchanger of the $\beta$ intercalated cells of the CCD as an important renal target of UGN, and have provided a possible novel explanation for a significant part of UGN-induced chloriuresis (Fig. 4). However, the identity of the intercalated cell membrane receptor that binds UGN and the signaling pathway by which UGN triggers HSF1 binding to the HSE of the PDS promoter to activate transcription both remain to be clarified.

\section{Potential Therapeutic Implications of Pendrin Inhibition}

Collectively, the accumulating data on the major role of pendrin in the regulation of fluid and electrolyte balance and the control of blood pressure (see above), including its interaction with several $\mathrm{Na}^{+}$- dependent transport processes in the distal tubule [73-75, 77], raise the possibility that specific inhibitors of pendrin may have a strong diuretic effect in conditions associated with elevated blood pressure and fluid retention states such as renal failure, heart failure and hepatic disease. 


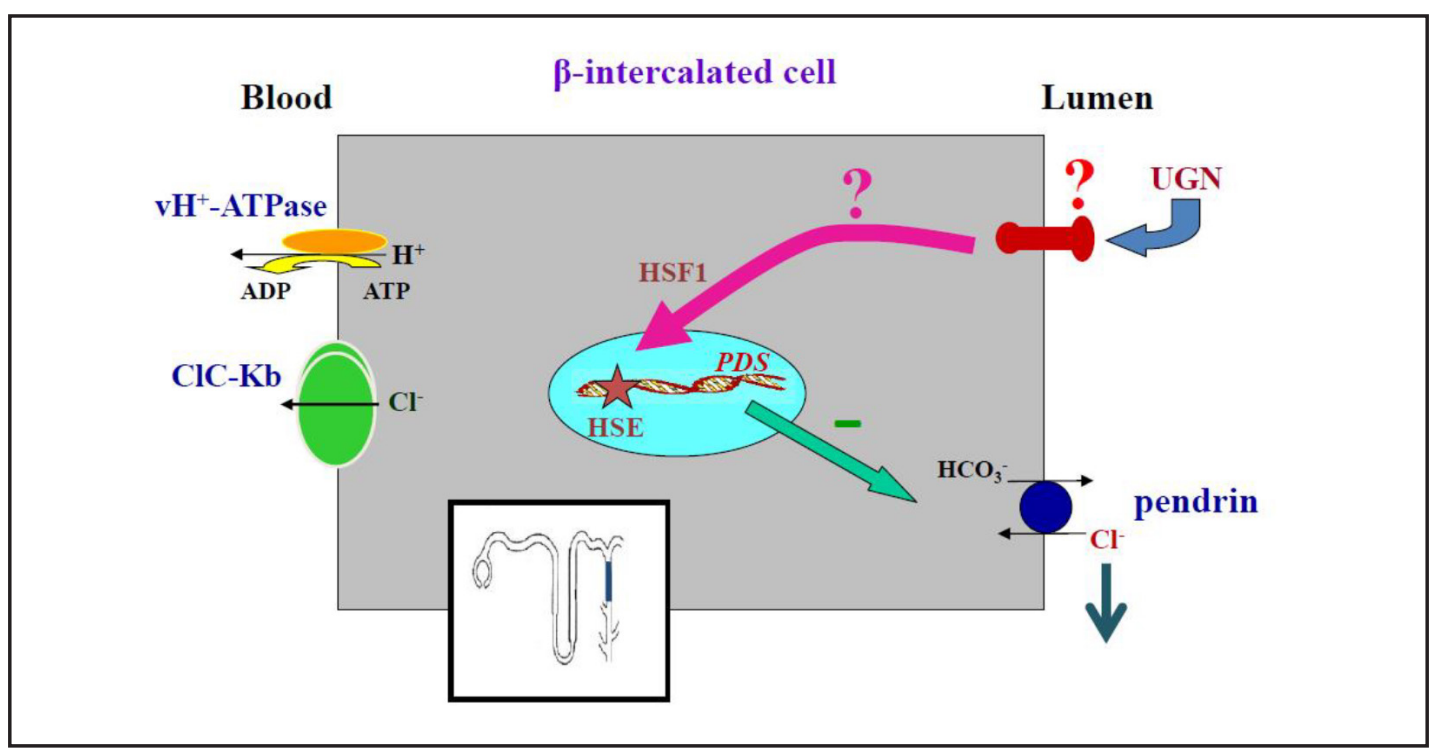

Fig. 4. A schematic model of the transcriptional inhibition of the pendrin gene (PDS) promoter by uroguanylin (UGN) in $\beta$-intercalated cells of the cortical collecting duct. This effect of UGN is achieved via heat shock factor 1 (HSF1) active at a defined heat shock element (HSE) site on the promoter. The membrane-associated receptor that binds UGN and the signal transduction pathway whereby UGN triggers HSF1 binding to HSE remain unidentified. $\mathrm{vH}^{+}$-ATPase, vacuolar type $\mathrm{H}^{+}$-ATPase (proton pump); $\mathrm{ClC}-\mathrm{Kb}$, voltage-gated $\mathrm{Cl}^{-}$channel $-\mathrm{Kb}$.

It remains to be determined whether the guanylin peptides, with their natriuretic/ diuretic action, in general, and their pendrin inhibiting/chloriuretic effect, in particular, may themselves become candidate diuretic agents. It is noteworthy, in this regard, that patients with chronic renal failure [21, 90], glomerulonephritis [22] and nephrotic syndrome [22] display increased plasma levels of guanylin peptides. In some of these disease states, such as in nephrotic syndrome [22, 91], UGN may be mobilized to act as a natriuretic factor.

\section{Non-Classical Roles of Guanylin Peptides:}

\section{Role of Guanylin Peptides in Appetite Regulation}

Of great interest is a recent report [92] identifying UGN as a satiety factor operating via the guanylyl cyclase 2C (GUCY2C) receptor expressed in the hypothalamus. Silencing of GUCY2C in mice disrupted satiation, resulting in hyperphagia and subsequent obesity and metabolic syndrome [92]. The same study demonstrated that nutrient intake induces intestinal prouroguanylin secretion into the circulation. The prohormone undergoes proteolytic conversion to bioactive UGN in the hypothalamus, inducing GUCY2C signaling and consequent activation of downstream anorexigenic pathways [92]. These data define an appetite-suppressing UGN-GUCY2C endocrine axis that regulates ingestion, energy homeostasis and body weight [92-94].

These findings on a unique, UGN-mediated component of the gut-brain axis controlling energy metabolism could lead to therapeutic interventions in obesity and the metabolic syndrome [93].

Role of Guanylin Peptides in Olfactory Function

GN and UGN were recently shown to play a role in odor sensation in the olfactory epithelium $[95,96]$. Odor recognition and transduction by canonical olfactory sensory neurons (OSNs) occurs through a G protein-coupled, cAMP-dependent signaling cascade 
[96-98]. However, Meyer et al. [97]. identified a subset of OSNs specifically expressing cGMP-signaling components (namely a guanylyl cyclase D (GC-D) and a cGMP-stimulated phosphodiesterase, PDE2) as well as a cGMP-gated channel (CGN), highlighting the role of cGMP in the physiology of these neurons. By using a combination of gene targeting of GUCY2D (which encodes GC-D), patch clamp recording and confocal $\mathrm{Ca}^{2+}$ imaging, Leinders-Zufall et al. [95] demonstrated that GC-D-expressing neuronal cells respond to guanylin and uroguanylin in a cGMP-dependent manner to induce action potentials in the olfactory epithelium. UGN has also been shown to work through the membrane-linked guanylyl cyclase GC-D/Gucy2d of olfactory sensory neurons to promote acquisition of novel food preferences [99].

This work identifies GN and UGN as mammalian semiochemicals (transmitters of chemical messages) recognized by a unique olfactory detection system [95, 99]. Furthermore, the findings of the studies raise the possibility that these peptide hormones, the levels of which rise postprandially, act as chemical signals communicating information related to salt and water balance and metabolic status to the olfactory epithelium $[96,98]$. It is plausible that both the guanylin peptide/GC-D-mediated stimuli transmitted to the olfactory epithelium and the UGN/GUCY2C-mediated stimuli conveyed to the hypothalamus described above, jointly contribute to the maintenance of salt, water and nutrient balance in the body.

\section{Role of Guanylin Peptides in Reproductive Function}

Several studies have demonstrated an effect of UGN on reproductive organs including the guinea pig uterus [100], rat epididymis [101] and human corpora cavernosa [5,102]. Uroguanylin relaxed oxytocin- induced contractions in the pregnant myometrium of guinea pig via a cGMP-dependent mechanism [100], likely involving membrane-bound GC-C of uterine myocytes. Differentially glycosylated forms of GC-C were found in rat epididymis and UGN elevated cGMP levels in epididymeal mices [101]. The findings of this study suggested that the UGN-GC-C-cGMP pathway could influence CFTR function in the epididymis, thereby controlling fluid and ion balance for optimal sperm maturation.

Similarly, UGN has been shown to relax human corpora cavernosa strips by a particulate GC-C/cGMP-dependent mechanism [102]. This UGN-stimulated pathway raises cGMP concentrations in a mechanism that is independent of and additive to the classical NOactivated soluble guanylyl cyclase-cGMP pathway, which is targeted by the PDE5 inhibitors widely used in treatment of male erectile dysfunction. Hence, these findings suggest targeting of particulate guanylyl cyclase receptors as an alternative treatment of erectile dysfunction, especially in patients with endothelial and nitrergic dysfunction such as diabetes $[5,98]$.

\section{Role of Guanylin Peptides in Cell Proliferation/Differentiation and Inflammation}

Beyond systemic volume homeostasis, GC-C/cGMP signal transduction mechanisms activated by GN and UGN regulate the formation of epithelial cells in the intestinal mucosa $[98,103]$. Pitari et al [104] have shown that GN and UGN can regulate the balance between epithelial proliferation and differentiation, and can regulate cell cycle progression in human colon carcinoma cell lines. The guanylin peptides show an antiproliferative action that involves stimulation of the GC-C/cGMP pathway and $\mathrm{Ca}^{2+}$ influx through cell surface-bound cyclic nucleotide-gated (CNG) channels [98].

GN and UGN are the two gene products whose expression is most commonly lost early in colorectal tumorigenesis $[105,106] . \mathrm{GN}^{-}$and $\mathrm{GC}-\mathrm{C}^{-/}$mice show increased proliferation of colonic epithelial cells [107] and abnormal crypt architecture [108]. GN and UGN exert a cytostatic effect on human colon carcinoma cells [109] and pancreatic cancer cells [110], and inhibit formation of cancerous intestinal polyps in mice [109]. Collectively, these data suggest that the UGN/GC-C/cGMP axis may have generalized antiproliferative properties in various organ systems $[98,103,110,111]$.

The bacterial heat-stable enterotoxin (STa) was demonstrated to suppress colon cancer cell proliferation by a GC-C-mediated signaling cascade [112]. In addition, the high incidence of intestinal infections with STa-producing enterotoxigenic E. coli in underdeveloped countries is accompanied by a relatively low incidence of colon cancer. These findings have led to the 
interesting speculation that the cytostatic/antiproliferative properties of the STa peptides could prevent proliferation of human cancer cells and provide resistance to intestinal cancer in underdeveloped countries, and could potentially be adapted for targeted prevention and therapy of colorectal cancer $[98,112]$.

Of great interest are recent studies on the role of GUCY2C and guanylin peptides in enteric inflammation [113-115]. The absence of GUCY2C in mice rendered them susceptible to more severe colitis due either to intraperitoneal lipopolysaccharide injection or to the genetic absence of interleukin-10 [113]. The genetically engineered absence of GUCY2C also increased severity of mucosal injury caused by the murine enteric pathogen $C$. rodentii, and decreased containment of the infection, associated with increased leukocyte infiltration, enterocyte apoptosis with loss of intestinal barrier function, elevated cytokine responses, and hepatic injury. The GUCY2C ligand UGN also exhibits analgesic efficacy in rat models of chemically and mechanically-stimulated visceral pain [114]. These data together have supported growing interest in development of stable GC-C agonists for clinical trials in the treatment of inflammaotry bowel diseases [115].

\section{Role of Guanylin Peptides in Airway Function}

The guanylin family of GC-C/cGMP-regulating peptides has been shown to be expressed in airway epithelium and to play a role in airway function $[4,16,116-119]$.

GN/UGN and the GC-C receptor have been identified in the apical membrane of bronchiolar nonciliated secretory (Clara) cells of rodents [16, 117]. Guanylin peptides operating via the GC-C/cGMP pathway were found to activate $\mathrm{Cl}^{-}$conductance in human airway epithelium through both the CFTR [117] and other $\mathrm{Cl}^{-}$-conductive pathways [119]. The latter finding, along with the localization of GC-C receptors primarily to the apical membrane of airway epithelium [117], raises the possibility of aerosol administration of guanylin peptides to CF patients for potential activation of non-CFTR anion conductance pathways [4]. Guanylin peptides have also been shown to exert a beneficial effect on airways of a guinea model of asthma, including a relaxant effect on ovalbumin-induced bronchoconstriction and leukotriene C4-induced airway microvascular leakage $[4,118,120]$.

Pendrin is highly expressed and its activity is upregulated at the apical membrane of bronchial epithelial cells following cytokine or antigen exposure, or in models of asthma or chronic obstructive lung disease [121-123]. The stimulated $\mathrm{Cl}^{-} / \mathrm{HCO}_{3}^{-}$exchange activity of pendrin results in increased production of mucus and increased viscosity of the airway surface liquid (ASL), thereby exacerbating airway disease [122, 123]. The cytokines interleukin 4 (IL-4) and interleukin-13 (IL-13), known triggers of airway hyperreactivity and disease, have been found to upregulate pendrin activity by transcriptional activation of the pendrin gene promoter $[79,124]$.

In view of the inhibitory effect of UGN on pendrin gene transcription in the kidney (Fig. 4 ), it will be very interesting to explore whether the guanylin peptides achieve their beneficial effect on airway function and disease by transcriptional inhibition of pendrin expression and activity in airway epithelium. Such a finding could potentially lead to the development of a novel, guanylin peptide - based therapeutic intervention in asthma, chronic obstructive lung disease and other airway diseases.

Noteworthy is a study showing that pendrin also functions in the bronchial epithelial cell as a $\mathrm{SCN}^{-} / \mathrm{CI}^{-}$exchanger [121]. Since $\mathrm{SCN}^{-}$is an anion with antioxidant/antimicrobial properties, the pendrin-mediated secretion of $\mathrm{SCN}^{-}$into the lumen (in exchange for $\mathrm{CI}^{-}$ entering the cell) may contribute to the innate defense of the mucosal surface $[121,125]$. Whether this effect of pendrin is influenced by UGN is a subject of future research.

\section{Conclusions}

Since the identification two decades ago of GN in rat jejunal extracts [126] and of UGN in opossum urine [127], ample data has accumulated on the biochemical characteristics 
and biological functions of guanylin peptides. This peptide family, which plays an important role in fluid and electrolyte homeostasis in the intestine and the kidney, has been shown to act via both endocrine and paracrine/autocrine mechanisms, through GC-C-dependent and -independent signal transduction pathways, in a variety of cellular processes, and in diverse organs. The renal anion exchanger pendrin, thought by some after its identification in 1997 [128] to participate merely in acid-base balance as a bicarbonate secretory pathway, has emerged as a major player in CCD Cl- transport, body volume regulation and blood pressure control. Transcriptional regulation of the pendrin gene by UGN creates a novel and unique connection between the intestine and the kidney, and an important link between two systems with major roles in electrolyte and water homeostasis. This link carries the potential for the development of a new promising class of diuretic agents.

The molecular identities of all the receptors and signaling pathways involved in the biological effects of the guanylin family on the pendrin anion exchanger remain to be established, as is also the case for potential links between these two systems in other organs such as the lung. Future research may unravel yet additional biological roles and modes of operation for these two important systems in various organs, suggesting new prospects for novel therapeutic approaches in multiple disease states.

\section{Conflict of Interests}

No conflict of interests.

\section{Acknowledgements}

I. Zelikovic was supported by the USA-Israel Binational Science Foundation, by the Rappaport Institute for Research in the Medical Sciences and by the Dr. Y. Rabinovitz Research Fund, Technion - Israel Institute of Technology; J. Rozenfeld and Orly Kladnitsky received support from the Dora and Sydney Gabrel Fund, and the Martin Kolinsky Fund, respectively, Rambam Medical Center, Haifa, Israel; SL Alper was supported by NIH grants DK43495 and DK34854 (Harvard Digestive Disease Center) and by the USA-Israel Binational Science Foundation; SL Carrithers was supported, in part, by NIH grants DK070374 and DK089892, and by KSTC-184-512-12-126. We thank Mrs. Ora Bider and Mrs. Laura Pinto-Ilyaguev for their expert secretarial assistance.

\section{References}

1 Fonteles MC, Greenberg RN, Monteiro HS, Currie MG and Forte LR: Natriuretic and kaliuretic activities of guanylin and uroguanylin in the isolated perfused rat kidney. Am J Physiol 1998;275:F191-F197.

-2 Kita T, Kitamura K, Sakata J and Eto T: Marked increase of guanylin secretion in response to salt loading in the rat small intestine. Am J Physiol 1999;277:G960-G966.

-3 Sindic A and Schlatter E: Cellular effects of guanylin and uroguanylin. J Am Soc Nephrol 2006;17:607-616.

4 Forte L.R: Uroguanylin and guanylin peptides: pharmacology and experimental therapeutics. Pharmacology \&Therapeutics 2004;104:137-167

-5 Fonteles M.C, Falcao do Nascimento N. R: Guanylin peptide family: history, interaction with ANP, and new pharmacological perspectives. Can J Physiol Pharmacol 2011;89:575-585.

6 de Sauvage FJ, Keshav S, Kuang WJ, Gillett N, Henzel W and Goeddel DV: Precursor structure, expression, and tissue distribution of human guanylin. Proc Natl Acad Sci USA 1992;89:9089-9093. 
7 Field M, Graf LH Jr, Laird WJ and Smith PL: Heat-stable enterotoxin of Escherichia coli: in vitro effects on guanylate cyclase activity, cyclic GMP concentration, and ion transport in small intestine. Proc Natl Acad Sci USA 1978; 75:2800-2804.

-8 Forte LR, Fan X and Hamra FK: Salt and water homeostasis: uroguanylin is a circulating peptide hormone with natriuretic activity. Am J Kidney Dis 1996;28:296-304.

-9 Hamra FK, Forte LR, Eber SL, Pidhorodeckyj NV, Krause WJ, Freeman RH, Chin DT, Tompkins JA, Fok KF, Smith CE, Duffin KL, Siegel NR, Currie MG: Uroguanylin: structure and activity of a second endogenous peptide that stimulates intestinal guanylate cyclase. Proc Natl Acad Sci USA 1993;90:10464-10468.

10 Hill O, Kuhn M, Zucht HD, Cetin Y, Kulaksiz H, Adermann K, Klock G, Rechkemmer G, Forssmann WG, Magert HJ: Analysis of the human guanylin gene and the processing and cellular localization of the peptide. Proc Natl Acad Sci USA 1995;92:2046-2050.

11 Magert HJ, Reinecke M, David I, Raab HR, Adermann K, Zucht HD, Hill O, Hess R, Forssmann WG: Uroguanylin: gene structure, expression, processing as a peptide hormone, and co-storage with somatostatin in gastrointestinal D-cells. Regul Pept 1998;73:165-176.

12 Fan X, Hamra FK, Freeman RH, Eber SL, Krause WJ, Lim RW, Pace VM, Currie MG, Forte LR: Uroguanylin: cloning of preprouroguanylin cDNA, mRNA expression in the intestine and heart and isolation of uroguanylin and prouroguanylin from plasma. Biochem Biophys Res Commun 1996;219:457-462.

13 Schulz S, Chrisman TD and Garbers DL: Cloning and expression of guanylin. Its existence in various mammalian tissues. J Biol Chem 1992;267:16019-16021.

14 Wada A, Hasegawa M, Matsumoto K, Niidome T, Kawano Y, Hidaka Y, Padilla PI, Kurazono H, Shimonishi Y, Hirayama T: The significance of Ser1029 of the heat-stable enterotoxin receptor (STaR): relation of STamediated guanylyl cyclase activation and signaling by phorbol myristate acetate. FEBS Lett 1996;384:75-77.

15 Miyazato M, Nakazato M, Matsukura S, Kangawa K, Matsuo H: Uroguanylin gene expression in the alimentary tract and extra-gastrointestinal tissues. FEBS Lett 1996;398:170-174.

- 16 Cetin Y, Kulaksiz H, Redecker P, Bargsten G, Adermann K, Grube D: Bronchiolar nonciliated secretory (Clara) cells: source of guanylin in the mammalian lung. Proc Natl Acad Sci USA 1995;92:5925-5929.

17 Hamra FK, Fan X, Krause WJ, Freeman RH, Chin DT, Smith CE, Currie MG, Forte LR: Prouroguanylin and proguanylin: purification from colon, structure, and modulation of bioactivity by proteases. Endocrinology 1996;137:257-265.

18 Moss NG, Fellner RC, Qian X, Yu SJ, Li Z, Nakazato M, Goy MF: Uroguanylin, an intestinal natriuretic peptide, is delivered to the kidney as an unprocessed propeptide. Endocrinology 2008;149:4486-4498.

19 Qian X, Moss NG, Fellner RC, Goy MF: Circulating prouroguanylin is processed to its active natriuretic form exclusively within the renal tubules. Endocrinology 2008;149:4499-4509.

20 Kuhn M, Raida M, Adermann K, Schulz-Knappe P, Gerzer R, Heim JM, Forssmann WG: The circulating bioactive form of human guanylin is a high molecular weight peptide (10.3 kDa). FEBS Lett 1993;318:205209.

21 Nakazato M, Yamaguchi H, Shiomi K, Date Y, Fujimoto S, Kangawa K, Matsuo H, Matsukura S: Identification of 10-kDa proguanylin as a major guanylin molecule in human intestine and plasma and its increase in renal insufficiency. Biochem Biophys Res Commun 1994;205:1966-1975.

22 Kinoshita H, Fujimoto S, Nakazato M, Yokota N, Date Y, Yamaguchi H, Hisanaga S, Eto T: Urine and plasma levels of uroguanylin and its molecular forms in renal diseases. Kidney Int 1997;52:1028-1034.

23 Nakazato M, Yamaguchi H, Kinoshita H, Kangawa K, Matsuo H, Chino N, Matsukura S: Identification of biologically active and inactive human uroguanylins in plasma and urine and their increases in renal insufficiency. Biochem Biophys Res Commun 1996;220:586-593.

24 Hamra FK, Krause WJ, Eber SL, Freeman RH, Smith CE, Currie MG, Forte LR: Colonic mucosa contains uroguanylin and guanylin peptides. Am J Physiol 1996;270:G708-G716.

25 Carrithers SL, Ott CE, Hill MJ, Johnson BR, Cai W, Chang JJ, Shah RG, Sun C, Mann EA, Fonteles MC, Forte LR, Jackson BA, Giannella RA, Greenberg RN: Guanylin and uroguanylin induce natriuresis in mice lacking guanylyl cyclase-C receptor. Kidney Int 2004;65:40-53.

-26 Sindic A, Schlatter E: Renal electrolyte effects of guanylin and uroguanylin. Curr Opin Nephrol Hypertens 2007;16:10-15.

27 Forte LR: A novel role for uroguanylin in the regulation of sodium balance. J Clin Invest 2003;112:11381141. 
28 Currie MG, Fok KF, Kato J, Moore RJ, Hamra FK, Duffin KL and Smith CE: Guanylin: an endogenous activator of intestinal guanylate cyclase. Proc Natl Acad Sci USA 1992;89:947-951.

29 Kita T, Smith CE, Fok KF, Duffin KL, Moore WM, Karabatsos PJ, Kachur JF, Hamra FK, Pidhorodeckyj NV, Forte LR: Characterization of human uroguanylin: a member of the guanylin peptide family. Am J Physiol 1994;266:F342-F348.

30 Cohen MB, Witte DP, Hawkins JA, Currie MG: Immunohistochemical localization of guanylin in the rat small intestine and colon. Biochem Biophys Res Commun 1995;209:803-808.

-31 Li Z, Taylor-Blake B, Light AR, Goy MF: Guanylin, an endogenous ligand for C-type guanylate cyclase, is produced by goblet cells in the rat intestine. Gastroenterology 1995;109:1863-1875.

32 Nakazato M, Yamaguchi H, Date Y, Miyazato M, Kangawa K, Goy MF, Chino N, Matsukura S: Tissue distribution, cellular source, and structural analysis of rat immunoreactive uroguanylin. Endocrinology 1998;139:5247-5254.

-33 Perkins A, Goy MF, Li Z: Uroguanylin is expressed by enterochromaffin cells in the rat gastrointestinal tract. Gastroenterology 1997;113:1007-1014.

-34 Qian X, Prabhakar S, Nandi A, Visweswariah SS, Goy MF: Expression of GC-C, a receptor-guanylate cyclase, and its endogenous ligands uroguanylin and guanylin along the rostrocaudal axis of the intestine. Endocrinology 2000;141:3210-3224.

-35 Fiskerstand T, Arshad N, Haukanes BI, Tronstad TR, Pham KDC, Johansson S, Havik B, Tonder SL, Levy SE, Brackman D, Boman H, Biswass KH, Apold J, Hovdenak N, Visweswariah SS, Knappskog PM: Familial diarrhea syndrome caused by an activating GUCY2C mutation. N Eng J Med 2012;366:1585-1595.

-36 Romi H, Cohen I, Landau D, Alkrinawi S, Yerushalmi B, Hershkovitz R, Newman-Heiman N, Cutting G, Ofir R, Sivan S, Birk O: Meconium ileus caused by mutations in GUCY2C Encoding the CFTR-activating guanylate cyclase 2C. Am J Hum Genet 2012;90:893-899.

- 37 Forte LR: Uroguanylin: physiological role as a natriuretic hormone. J Am Soc Nephrol_2005;16:291-292.

-38 Michell AR, Debnam ES, Unwin RJ: Regulation of renal function by the gastrointestinal tract: potential role of gut-derived peptides and hormones. Annu Rev Physiol 2008;70:379-403.

-39 Mu JY, Hansson GC, Lundgren O: The intestinal tract and the pathophysiology of arterial hypertension: an experimental study on Dahl rats. Acta Physiol Scand 1995;155:137-146.

40 Lennane RJ, Peart WS, Carey RM, Shaw J: A comparison on natriuresis after oral and intravenous sodium loading in sodium-depleted rabbits: evidence for a gastrointestinal or portal monitor of sodium intake. Clin Sci 1975;49:433-436.

41 Carey RM, Smith JR, Ortt EM: Gastrointestinal control of sodium excretion in sodium-depleted conscious rabbits, Am J Physiol 1976;230:1504-1508.

-42 Carey RM: Evidence for a splanchnic sodium input monitor regulating renal sodium excretion in man. Lack of dependence upon aldosterone. Circ Res 1978;43:19-23.

43 Lennane RJ, Carey RM, Goodwin TJ, Peart WS: A comparison of natriuresis after oral and intravenous sodium loading in sodium-depleted man: evidence for a gastrointestinal or portal monitor of sodium intake. Clin Sci 1975;49:437-440.

-44 Singer DR, Markandu ND, Buckley MG, Miller MA, Sagnella GA, MacGregor GA: Contrasting endocrine responses to acute oral compared with intravenous sodium loading in normal humans. Am J Physiol 1998;274:F111-F119,

-45 Lorenz JN, Nieman M, Sabo J, Sanford LP, Hawkins JA, Elitsur N, Gawenis LR, Clarke LL, Cohen MB: Uroguanylin knockout mice have increased blood pressure and impaired natriuretic response to enteral $\mathrm{NaCl}$ load. J Clin Invest 2003;112:1244-1254.

46 Greenberg RN, Hill M, Crytzer J, Krause WJ, Eber SL, Hamra FK, and Forte LR: Comparison of effects of uroguanylin, guanylin, and Escherichia coli heat-stable enterotoxin STa in mouse intestine and kidney: evidence that uroguanylin is an intestinal natriuretic hormone. J Investig Med 1997;45:276-282.

47 Moss NG, Riguera DA, Solinga RM, Kessler MM, Zimmer DP, Arendshorst WJ, Currie MG, Goy MF: The natriuretic peptide uroguanylin elicits physiologic actions through 2 distinct topoisomers. Hypertension 2009;53:867-876.

48 Mueller T, Dieplinger B: The guanylin peptide family and proposed gastrointestinal-renal natriuretic signaling axis. Kidney Int 2012;82:1253-1255. 
49 Qian X, Moss NC, Fellner RC, Taylor-Blake B, Goy MF: The rat kidney contains high levels of prouroguanylin (the uroguanylin precursor) but does not express GC-C (the enteric uroguanylin receptor). Am J Physiol Renal Physiol 2011;300:F561-F573.

50 Carrithers SL, Taylor B, Cai WY, Johnson BR, Ott CE, Greenberg RN, Jackson BA: Guanylyl cyclase-C receptor mRNA distribution along the rat nephron. Regul Pept 2002;95:65-74.

51 Fujimoto S, Kinoshita H, Hara S, Nakazato M, Hisanaga S, Eto T: Immunohistochemical localization of uroguanylin in the human kidney. Nephron 2000;84:88-89.

-52 Potthast, R., Ehler, E., Scheving, L. A., Sindic, A., Schlatter, E, Kuhn, M: High salt intake increases uroguanylin expression in mouse kidney. Endocrinology 2001;142:3087-3097.

-53 Fukae H, Kinoshita H, Fujimoto S, Kita T, Nakazato M, Eto T: Changes in urinary levels and renal expression of uroguanylin on low or high salt diets in rats. Nephron 2002;92:373-378.

54 Elitsur N, Lorenz JN, Hawkins JA, Rudolph JA, Witte D, Yang LE, McDonough AA, Cohen MB: The proximal convoluted tubule is a target for the uroguanylin-regulated natriuretic response. J Pediatr Gastroenterol Nutr 2006;43:S74-S81.

-55 Sindic A, Schlatter E: Mechanisms of actions of guanylin peptides in the kidney. Pflugers Arch - Eur J Physiol 2005;450:283-291

-56 Steinbrecher KA, Rudolph JA, Luo G, Cohen MB: Coordinate upregulation of guanylin and uroguanylin expression by hypertonicity in HT29-18-N2 cells. Am J Physiol Cell Physiol 2002;283:C1729-C1737.

-57 Preston RA, Afshartous D, Forte LR, Rodco R, Alonso AB, Garg D, Raij L: Sodium challenge does not support an acute gastrointestinal-renal natriuretic signaling axis in human. Kidney Int 2012;82:1313-1320.

-58 Sindic A, Hirsch JR, Velic A, Piechota H, Schlatter E: Guanylin and uroguanylin regulate electrolyte transport in isolated human cortical collecting ducts. Kidney Int 2005;67:1420-1427.

-59 Sindic A, Schlatter E: Mechanisms of action of uroguanylin and guanylin and their role in salt handling. Nephrol Dial Transplant 2006;21:3007-3012.

- 60 Sindic A, Basoglu C, Cerci A, Hirsch JR, Potthast R, Kuhn M, Ghanekar Y, Visweswariah SS, Schlatter E: Guanylin, uroguanylin, and heat-stable euterotoxin activate guanylate cyclase $\mathrm{C}$ and/or a pertussis toxinsensitive G protein in human proximal tubule cells. J Biol Chem 2002;277:17758-17764.

-61 Sindic A, Velic A, Basoglu C, Hirsch JR, Edemir B, Kuhn M, Schlatter E: Uroguanylin and guanylin regulate transport of mouse cortical collecting duct independent of guanylate cyclase C. Kidney Int 2005;68:10081017.

62 Schwartz GJ: Plasticity of intercalated cell polarity: effect of metabolic acidosis. Nephron 2001;87:304-313.

63 Royaux IE, Wall SM, Karniski LP, Everett LA, Suzuki K, Knepper MA, Green ED: Pendrin, encoded by the Pendred syndrome gene, resides in the apical region of renal intercalated cells and mediates bicarbonate secretion. Proc Natl Acad Sci USA 2001;98:4221-4226.

-64 Verlander JW, Hassell KA, Royaux IE, Glapion DM, Wang ME, Everett LA, Green ED, Wall SM: Deoxycorticosterone upregulates PDS (Slc26a4) in mouse kidney: role of pendrin in mineralocorticoidinduced hypertension. Hypertension 2003;42:356-362.

-65 Quentin F, Chambrey R, Trinh-Trang-Tan MM, Fysekidis M, Cambillau M, Paillard M, Aronson PS, Eladari $\mathrm{D}$ : The $\mathrm{Cl}^{-} / \mathrm{HCO}_{3}-$ exchanger pendrin in the rat kidney is regulated in response to chronic alterations in chloride balance. Am J Physiol Renal Physiol 2004;287:F1179-1188.

-66 Vallet M, Picard N, Loffing-Cueni D, Fysekidis M, Bloch-Faure M, Deschênes G, Breton S, Meneton P, Loffing J, Aronson PS, Chambrey R, Eladari D: Pendrin regulation in mouse kidney primarily is chloridedependent. J Am Soc Nephrol 2006;17:2153-2163.

-67 Frische S, Kwon TH, Frokiaer J, Madsen KM, Nielsen S: Regulated expression of pendrin in rat kidney in response to chronic $\mathrm{NH}_{4} \mathrm{Cl}$ or $\mathrm{NaHCO}_{3}$ loading. Am J Physiol Renal Physiol 2003;284:F584-F593.

68 Petrovic S, Wang Z, Ma L, Soleimani M: Regulation of the apical $\mathrm{Cl}^{-} / \mathrm{HCO}_{3}$ - exchanger pendrin in rat cortical collecting duct in metabolic acidosis. Am J Physiol Renal Physiol 2003;284:F103-F112.

-69 Wagner CA, Finberg KE, Stehberger PA, Lifton RP, Giebisch GH, Aronson PS, Geibel JP: Regulation of the expression of the $\mathrm{Cl}$ /anion exchanger pendrin in mouse kidney by acid-base status. Kidney Int 2002;62:2109-2117.

-70 Verlander JW, Kim YH, Shin W, Pham TD, Hassell KA, Beierwaltes WH, Green ED, Everett L, Matthews SW, Wall SM: Dietary $\mathrm{Cl}^{-}$restriction upregulates pendrin expression within the apical plasma membrane of type B intercalated cells. Am J Physiol Renal Physiol 2006;291:F833-F839. 
71 Pech V, Kim HY, Weinstein MA, Everett AL, Pham DT, Wall MS: Angiotensin II increases chloride absorption in the cortical collecting duct in mice through a pendrin-dependent mechanism. Am J Physiol Renal Physiol 2007;292:F914-F920.

72 Verlander JW, Hong S, Pech V, Bailey JL, Agazatian D, Matthews SW, Coffman TM, Le T, Inagami T, Whitehill FM, Weiner ID, Farley DB, Kim YH, Wall SM: Angiotensin II acts through the angiotensin 1a receptor to upregulate pendrin. Am J Physiol Renal Physiol 2011;301:F1314-F1325.

73 Kim YH, Pech V, Spencer KB, Beierwaltes WH, Everett LA, Green ED, Shin W, Verlander JW, Sutliff RL, Wall SM: Reduced ENaC protein abundance contributes to the lower blood pressure observed in pendrin-null mice. Am J Physiol Renal Physiol 2007;293:F1314-F1324.

74 Pech V, Pham TD, Hong S, Weinstein AM, Spencer KB, Duke BJ, Walp E, Kim YH, Sutliff RL, Bao HF, Eaton DC, Wall SM: Pendrin modulates ENaC function by changing luminal $\mathrm{HCO}_{3}$. J Am Soc Nephrol 2010;21:19281941.

75 Leviel F, Hubner CA, Houillier P, Morla L, El Moghrabi S, Brideau G, Hatim H, Parker MD, Kurth I, Kougioumtzes A, Sinning A, Pech V, Riemondy KA, Miller RL, Hummler E, Shull GE, Aronson PS, Doucet A, Wall SM, Chambrey R, Eladari D: The $\mathrm{Na}^{+}$-dependent chloride-bicarbonate exchanger SLC4A8 mediates an electroneutral $\mathrm{Na}^{+}$reabsorption process in the renal cortical collecting ducts of mice. J Clin Invest 2010;120:1627-1635.

76 Jacques T, Picard N, Miller RL, Riemondy KA, Houillier P, Sohet F, Ramakrishnan SK, Busst CJ, Jayat M, Corniere N, Hassan H, Aronson PS, Hennings JC, Hubner CA, Nelson RD, Chambrey R, Eladari D: Overexpression of pendrin in intercalated cells produces chloride-sensitive hypertension. J Am Soc Nephrol 2013;24:1104-1113.

77 Soleimani M, Barone S, Xu J, Shull GF, Siddiqui F, Zahedi K, Amlal H: Double knockout of pendrin and Na-Cl cotransporter (NCC) causes severe salt wasting, volume depletion, and renal failure. Proc Natl Acad Sci USA 2012;109:13368-13373.

78 Adler L, Efrati E and Zelikovic I: Molecular mechanisms of epithelial cell-specific expression and regulation of the human anion exchanger (pendrin) gene. Am J Physiol Cell Physiol 2008;294,C1261-C1276.

79 Rozenfeld J, Efrati E, Adler L, Tal O, Carrithers SL, Alper SL, Zelikovic I: Transcription regulation of the pendrin gene. Cell Physiol Biochem 2011;28:385-396.

80 Efrati E, Adler L, Tal O, Zelikovic I: The pendrin gene, PDS, is transcriptionally regulated by ambient $\mathrm{pH}$ and chloride. J Am Soc Nephrol 2007;8:6A.

81 Rozenfeld J, Tal O, Kladnitsky O, Adler L, Efrati E, Carrithers SL, Alper SL, Zelikovic I: The pendrin anion exchanger gene is transcriptionally regulated by uroguanylin: a novel enterorenal link. Am J Physiol Renal Physiol 2012;302:F614-F624.

82 Anckar J, Sistonen L: Heat shock factor 1 as a coordinator of stress and developmental pathways. Adv Exp Med Biol 2007;594:78-88.

83 Morimoto RI: Proteotoxic stress and inducible chaperone networks in neurodegenerative disease and aging. Genes Dev 2008;22:1427-1438.

84 Morimoto RI, Santoro MG: Stress-inducible responses and heat shock proteins: new pharmacologic targets for cytoprotection. Nat Biotechnol 1998;16:833-838.

85 Dokladny K, Ye D, Kennedy JC, Moseley PL, Ma TY: Cellular and molecular mechanisms of heat stressinduced up-regulation of occludin protein expression: regulatory role of heat shock factor-1. Am J Pathol 2008;172:659-670.

86 Trinklein ND, Murray JI, Hartman SJ, Botstein D, Myers RM: The role of heat shock transcription factor 1 in the genome-wide regulation of the mammalian heat shock response. Mol Biol Cell 2004;15:1254-1261.

-87 Vilaboa NE, Galán A, Troyano A, de Blas E, Aller P: Regulation of multidrug resistance 1 (MDR1)/Pglycoprotein gene expression and activity by heat-shock transcription factor 1 (HSF1). J Biol Chem 2000;275:24970-24976.

88 Comrie MM, Cutler CP, Cramb G: Cloning and expression of guanylin from the European eel (Anguilla anguilla). Biochem Biophys Res Commun 2001;281:1078-1085.

89 Yuge S, Inoue K, Hyodo S, Takei Y: A novel guanylin family (guanylin, uroguanylin, and renoguanylin) in eels: possible osmoregulatory hormones in intestine and kidney. J Biol Chem 2003;278:22726-22733.

90 Fukae H, Kinoshita H, Fujimoto S, Nakazato M, Eto T: Plasma concentration of uroguanylin in patients on maintenance dialysis therapy. Nephron 2000;84:206-210. 
91 Kikuchi M, Fujimoto S, Fukae H, Kinoshita H, Kita T, Nakazato M, Eto T: Role of uroguanylin, a Peptide with natriuretic activity, in rats with experimental nephrotic syndrome. J Am Soc Nephrol 2005;16:392-397.

-92 Valentino M, Lin J, Snook A, Li P, Kim G, Marszalowicz G, Magee M, Hyslop T, Schulz S, Waldman S: A uroguanylin-GUCY2C endocrine axis regulates feeding in mice. J Clin Invest 2011;121:3578-3588.

-93 Seeley RJ, Tschop MH: Uroguanylin: how the gut got another satiety hormone. J Clin Invest 2011;121:33843386.

-94 Fruhbeck G: Uroguanylin-a new gut-derived weapon against obesity? Nat Rev Endocrinol 2012;8:5-6.

-95 Leinders-Zufall T, Cockerham RE, Michalakis S, Biel M, Garbers DL, Reed RR, Zufall F, Munger SD: Contribution of the receptor guanylyl cyclase GC-D to chemosensory function in the olfactory epithelium. Proc Natl Acad Sci USA 2007;104:14507-14512.

-96 Zufall F, Munger SD: Receptor guanylyl cyclases in mammalian olfactory function. Mol Cell Biochem 2010;334:191-197.

-97 Meyer MR, Angele A, Kremmer E, Kaupp UB, Muller F: A cGMP-signaling pathway in a subset of olfactory sensory neurons. Proc Natl Acad Sci USA 2000;97:10595-10600.

-98 Basu N, Visweswariah SS: Defying the stereotype: non-canonical roles of the peptide hormones guanylin and uroguanylin. Front Endocrinol 2011;2:1-5.

-99 Arakawa H, Kelliher KR, Zufall F, Munger SD: The receptor guanylyl cyclase type D (GC-D) ligand uroguanylin promotes the acquisition of food preferences in mice. Chem Senses 2013;38:391-397.

100 Buxton IL, Milton D, Barnett SD, Tichenor SD: Agonist- specific compartmentation of cGMP action in myometrium. J Pharmacol Exp Ther 2010;335:256-263.

-101 Jaleel M, London RM, Eber SL, Forte LR, Visweswariah SS: Expression of the receptor guanylyl cyclase Cand its ligands in reproductive tissues of the rat: a potential role for a novel signaling pathway in the epididymis. Biol Reprod 2002;67:1975-1980.

-102 Sousa CM, Havt A, Santos CF, Arnaud-Batista FJ, Cunha KM, Cerqueira JB, Fonteles MC, Nascimento NR: The relaxation induced by uroguanylin and the expression of natriuretic peptide receptors in human corpora cavernosa. J Sex Med 2010;7:3610-3619.

103 Rahbi H, Narayan H, Jones DJL, Ng LL: The uroguanylin system and human disease. Clin Sci 2012;123:659668.

104 Pitari GM, Di Guglielmo MD, Park J, Schulz S, Waldman SA: Guanylyl cyclase C agonists regulate progression through the cell cycle of human colon carcinoma cells. Proc Natl Acad Sci USA 2001;98:7846-7851.

105 Notterman DA, Alon U, Sierk AJ, Levine AJ: Transcriptional gene expression profiles of colorectal adenoma, adenocarcinoma, and normal tissue examined by oligonucleotide arrays. Cancer Res 2001;61:3124-3130.

106 Steinbrecher KA, Tuohy TM, Heppner Goss K, Scott MC, Witte DP, Groden J, Cohen MB: Expression of guanylin is downregulated in mouse and human intestinal adenomas. Biochem. Biophys Res Commun 2000;273:225-230.

107 Steinbrecher KA, Wowk SA, Rudolph JA, Witte DP, Cohen MB: Targeted inactivation of the mouse guanylin gene results in altered dynamics of colonic epithelial proliferation. Am J Pathol 2002;161:2169-2178.

108 Li P, Lin JE, Chervoneva I, Schulz S, Waldman SA, Pitari GM: Homeostatic control of the crypt-villus axis by the bacterial enterotoxin receptor guanylyl cyclase $\mathrm{C}$ restricts the proliferating compartment in intestine. Am J Pathol 2007;171:1847-1858.

109 Shailubhai K, Yu HH, Karunanandaa K, Wang JY, Eber SL, Wang Y, Joo NS, Kim HD, Miedema BW, Abbas SZ: Uroguanylin treatment suppresses polyp formation in the ApcMin/+mouse and induces apoptosis in human colon adenocarcinoma cells via cyclic GMP. Cancer Res 2000;60:5151-5157.

110 Kloeters O, Friess H, Giese N, Buechler MW, Cetin Y, Kulaksiz H: Uroguanylin inhibits proliferation of pancreatic cancer cells. Scand J Gastroenterol 2008;43:447-455.

111 Li P, Lin JE, Schulz S, Pitari GM, Waldman SA: Can colorectal cancer be prevented or treated by oral hormone replacement therapy? Curr Mol Pharmacol 2009;2:285-292.

112 Pitari GM, Zingman LV, Hodgson DM, Alekseev AE, Kazerounian S, Bienengraeber M, Hajnoczky G, Terzic A, Waldman SA: Bacterial enterotoxins are associated with resistance to colon cancer. Proc Natl Acad Sci USA 2003;100:2695-2699.

113 Harmel-Laws E, Mann EA, Cohen MB: Guanylate cyclase C deficiency causes severe inflammation in a murine model of spontaneous colitis. PloS One. 2013;8:e79180. 
114 Silos-Santiago I, Hannig G, Eutamene H, Ustinova EE, Bernier SG, Ge P, Graul C, Jacobson S, Jin H, Liong E, Kessler MM, Reza T, Rivers S, Shea C, Tchernychev B, Bryant AP, Kurtz CB, Bueno L, Pezzone MA, Currie MG: Gastrointestinal pain : Unraveling a novel endogenous pathway through uroguanylin/guanylate cyclase-C/ cGMP activation. Pain 2013;154;1820-1830.

115 Pitari MG: Pharmacology and clinical potential of guanylyl cyclase $\mathrm{C}$ agonists in the treatment of ulcerative colitis. Drug Des Devel Ther 2013;7:351-360.

116 Krause WJ, Freeman RH, Forte LR: Autoradiographic demonstration of specific binding sites for E. coli enterotoxin in various epithelia of the North American opossum. Cell Tissue Res 1990;260:387-394.

-117 Kulaksiz H, Schmid A, Honscheid M, Ramaswamy A, Certin Y: Clara cell impact in air-side activation of CFTR in small pulmonary airways. Proc Natl Acad Sci USA 2002;99:6796-6801.

118 Ohbayashi K, Yamaki KI: Both Inhalant and intravenous uroguanylin inhibit leukotrience C 4-induced airway changes. Peptides 2000;21:1467-1472.

119 Zhang ZH, Jow F, Numann R, Hinson J: The airway epithelium: a novel site of action by guanylin. Biochem Biophys Res Commun 1998;244:50-56.

120 Ohbayashi K. Yamaki K, Suzuki R, Takagi K: Effects of uroguanylin and guanylin against antigen-induced bronchoconstriction and airway microvascular leakage in sensitized guinea pigs. Life Sci 1998;62:18331844.

-121 Pedemonte N, Caci E, Sondo E, Caputo A, Rhoden K, Pfeffer U, Di Candia M, Bandettini R, Ravazzolo R, Zegarra- Moran O, Galietta LJ: Thiocyanate transport in resting and IL-4-stimulated human bronchial epithelial cells: role of pendrin and anion channels. J Immunol 2007;178:5144-5153.

-122 Nakagami Y, Favoreto SJr, Zhen G, Park SW, Nguyenvu LT, Kuperman DA, Dolganov GM, Huang X, Boushey HA, Avila PC, Erle DJ: The epithelial anion transporter pendrin is induced by allergy and rhinovirus infection, regulates airway surface liquid, and increases airway reactivity and inflammation in an asthma model. J Immunol 2008;181:2203-2010.

123 Nakao I, Kanaji S, Ohta S, Matsushita H, Arima K, Yuyama N, Yamaya M, Nakayama K, Kubo H, Watanabe M, Sagara H, Sugiyama K, Tanaka H, Toda S, Hayashi H, Inoue H, Hoshino T, Shiraki A, Inoue M, Suzuki K, Aizawa H, Okinami S, Nagai H, Hasegawa M, Fukuda T, Green ED, Izuhara K: Identification of pendrin as a common mediator for mucus production in bronchial asthma and chronic obstructive pulmonary disease. J Immunol 2008;180:6262-6269.

124 Nofziger C, Vezzoli V, Dossena S, Schonherr T, Studnicka J, Nofziger J, Vanoni S, Stephan S, Silva ME, Meyer G, Paulmichl M: STAT6 links IL-4/IL-13 stimulation with pendrin expression in asthma and chronic obstructive pulmonary disease. Clin Pharmacol Ther 2011;90:399-405.

125 Adams KM, Abraham V, Cohen N, Kolls JK, Kreindler JL: Pendrin is a part of antimicrobial responses in the lung. Am J Respir Crit Care Med 2013;187:A4741.

126 Currie MG, Fok KF, Kato J, Moore RJ, Hamra FK, Duffin KL, Smith CE: Guanylin: an endogenous activator of intestinal guanylate cyclase. Proc Natl Acad Sci USA1992;89:947-951.

-127 Hamra FK, Forte LR, Eber SL, Pidhorodeckyj NV, Krause WJ, Freeman RH, Chin DT, Tompkins JA, Fok KF, Smith CE, Duffin KL, Siegel NR, Currie MG: Uroguanylin: structure and activity of asecond endogenous peptide that stimulates intestinal guanylate cyclase. Proc Natl Acad Sci USA1993;90:10464-10468.

128 Everett LA, Glaser B, Beck JC, Idol JR, Buchs A, Heyman M, Adawi F, Hazani E, Nassir E, Baxevanis AD, Sheffield VC, Green ED: Pendred syndrome is caused by mutations in a putative sulphate transporter gene (PDS). Nat Genet 1997;17:411-422. 